\title{
Visual Evaluation of Soil Structure (VESS) Method to Assess Soil Properties of Agroforestry System in Pangalengan, West Java
}

\author{
Bima Dwi Siswanto Aji ${ }^{1 *}$, Nurheni Wijayanto ${ }^{2}$, Basuki Wasis ${ }^{2}$ \\ ${ }^{1}$ Graduate Program of Tropical Silviculture, Faculty of Forestry and Environment, IPB University, Academic Ring Road, \\ Campus IPB Dramaga, Bogor, Indonesia 16680 \\ ${ }^{2}$ Department of Silviculture, Faculty of Forestry and Environment, IPB University, Academic Ring Road, \\ Campus IPB Dramaga, Bogor, Indonesia 16680
}

Received October 27, 2020/Accepted June 22, 2021

\begin{abstract}
Agroforestry is an alternative land use that not only provides benefits in economic aspects, but also in ecological aspects including improving soil quality. This research aims to evaluate the physical quality of soil in various types of land use, including agroforestry systems and evaluate the efficiency of the VESS method in determining soil physical quality. This study uses the VESS method to analyze soil quality in six land uses in Pangalengan, West Java (i.e. agroforestry, forest, tea plantations, coffee plantations, agriculture cultivation, and abandoned land). It used The VESS method because it has been widely applied in many countries, but has never been applied in Indonesia. Soil property parameters (BD, soil porosity, soil permeability, and SOC) were measured to correlate with the VESS score. VESS score ranged from 1 (good soil quality) to 5 (poor soil quality). The VESS score for each land type ranged from $S q$ 1.3-4.33. The soil quality in agroforestry $(S q$ 1.89-2.04) is not much different from natural forest (Sq 1.3). The VESS score has strong correlation $(r)$ with soil property parameters $(B D=0.97$, soil porosity $=-0.97$, soil permeability $=-0.83$, SOC $=-0.94)$. A Strong correlation value indicates that the VESS method can be used to analyze soil quality.
\end{abstract}

Keywords: agroforestry, correlation, soil property parameters, soil quality, VESS method

*Correspondentauthor,email: bima_dwi@apps.ipb.ac.id,tel.+62-251-8621947,fax. +62-251-8621256

\section{Introduction}

Indonesia is a country that has a large tropical forest area. Tropical forests in Indonesia are increasingly threatened in the last few years. Based on data by WRI (World Research Institute), in 2019 Indonesia was the third-largest country to lose tropical forest cover in the last 10 years with 324,000 ha. The forest conversion into agricultural land is one of the factors causing deforestation in Indonesia. It can cause environmental degradation, including a decrease in the physical quality of the soil, increasing bulk density and soil vulnerability to penetration, reducing soil aeration, affecting soil infiltration, and increasing the risk of erosion (Cherubin et al., 2016a).

Agroforestry is a form of land optimization management with a combination of tree crops (forestry) and seasonal crops (agriculture) which can also be combined with livestock. The application of agroforestry is not only beneficial in the economic aspect, but also in ecological aspects, including improving soil quality, closer to the quality of the soil in natural forest stands (Silva et al., 2011). Soil structure is one of the physical properties of soil which describes the shape, size and stability of soil. The concept of soil structure is often used to describe soil aggregates (Ghezzehei, 2012). Soil structure is relevant for describing the quality of soil, particularly the relationship between soil and water functions
(Prasetya et al., 2012; Rahmayuni \& Rosneti, 2017; Rabot et al., 2018). One of the factors influencing soil aggregate is organic matter. According to Setyowati (2007), high organic matter content is usually found in forests. Based on (Schumacher \& Riedell, 2008), organic matter comes from plant debris. It is utilized by soil organisms as food. That activity imparting mechanical and chemical processes that can cause soil particles to move, forming pores with various shapes and sizes. Organic matter content affects the physical properties of soil. The content of organic matter also affects the quality of soil aggregates, both in terms of stability and quality (Undang \& Nurida, 2009). In Pangalengan, Bandung, West Java, there are agroforestry systems that are quite good and have been managed for a long time. Further, we also found other land use here, such as potato fields, tea and coffee plantations. The difference in types of land use in Pangalengan is one of the reasons for conducting this research, particularly comparing soil quality in agroforestry with the other types of land use.

Visual evaluation of soil structure (VESS) is one of the methods used to measure the quality of soil through soil structure assessment. This method was developed by Ball et al. (2007). This method is considered simple enough to describe soil quality through its structural components. The VESS method has been widely used to analyze soil quality at 
various land covers. Cui et al. (2014) suggested that the VESS method was suitable to analyze the quality of soil structure for grassland productivity in Ireland. VESS is also used in the USA to evaluate soil structural quality on croplands (Tormena et al., 2016). VESS continues to be used and developed. Cherubin et al. (2017) concluded that the VESS scores provide an efficient method to analyzed the impacts of sugarcane expansion on soil structural quality and recommended that VESS assessment be incorporated into monitoring protocols for evaluating soil quality in Brazil. Cherubin et al. (2019) used the VESS in a larger scope in the Colombian Amazon region. VESS method is used to evaluate soil quality in natural forest, pasture, and diversified agroforestry systems. In Indonesia, the VESS method has not been widely studied, especially in the agroforestry area. Therefore, it is necessary to conduct research on soil quality evaluation in the agroforestry area using the VESS method. This study aims to evaluate the physical quality of soil in various types of land use, including agroforestry area, and evaluate the efficiency of the VESS method in determining the soil's physical quality.

\section{Methods}

Time and location This research conducted on July 2020-August 2020, at Pangalengan, Bandung Regency, West Java $(1,446 \mathrm{~m}$ above sea level). This area has an annual precipitation of $1,996 \mathrm{~mm}$ with the amount of rain for 5 months. The average daily temperature is $15-20^{\circ} \mathrm{C}$. The soil type in this area is andosol. Analysis of soil physical properties was carried out at Forest Influence Laboratorium, Faculty of Forestry, Bogor Agricultural University and Environmental Biotechnology Laboratory (EBL), Bogor.

We selected six types of land uses (Figure 1) in Pangalengan, as follows: (1) agroforestry with two patterns, namely complex agroforestry which consist of eucalyptus stands (Eucalyptus sp.), biwa (Eriobotrya japonica), jackfruit (Artocarpus heterophyllus), suren (Toona sureni), coffee plants (Coffea arabica), and simple agroforestry which consist eucalyptus stands (Eucalyptus sp.) and coffee plants (Coffea arabica), (2) natural forest cover, which consists natural stands of Castanopsis sp., Rubiaceae natural stands and palms, (3) potato fields, (4) coffee plantations (Coffea arabica), (5) tea plantations, and (6) abandoned land.

VESS method VESS method is a development of the Peerlkamp spade test. The sizes and shapes, visible porous, and roots distribution of soil aggregates and fragments are the key factors in determining soil structural quality. Assessment of soil quality was carried out at each layer (if there is more than one layer in the soil sample). Characteristics of each layer were then compared to the VESS scoring chart to give a soil quality score. The VESS score was classified from Sq 1 (good soil quality) to $\mathrm{Sq} 5$ (the worst soil quality). Detailed instructions of soil quality assessment on the VESS method have been completely described by Ball et al. (2007), improved by Guimaraes et al. (2011) and Ball et al. (2016).

Soil samples were taken three repetitions for each research site. A simple overview of the steps of the VESS method is as follows:

1. The soil was excavated with a size of about $30 \times 30 \times 30$ $\mathrm{cm}$, and then obtained by an undisturbed soil sample (block of soil) measured $20 \times 10 \times 15 \mathrm{~cm}$ by cutting it using a machete. If the soil is too hard, then the excavation is made wider in order to obtain undisturbed soil block samples.

2. The number of layers contained in the soil block sample was observed. If there are two or more layers in the soil block sample, the soil structure scoring is carried out at each soil block.

3. The soil aggregate was observed in the sample by crushing the soil blocks using both hands.

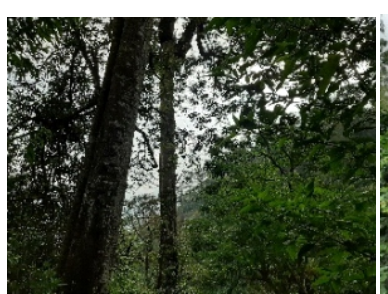

(a)

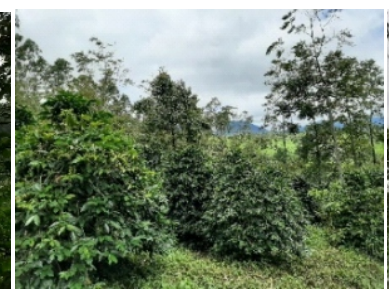

(b)

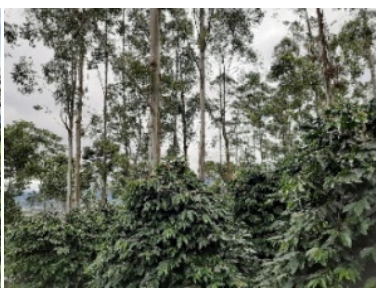

(c)

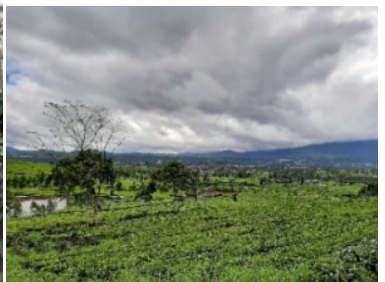

(d)

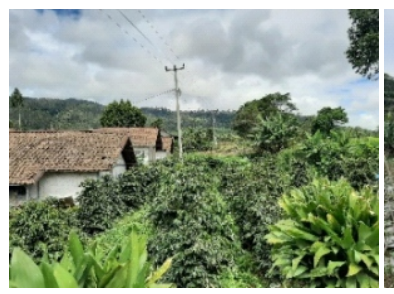

(e)

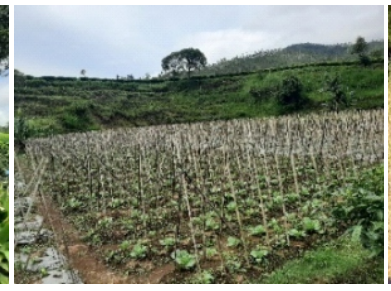

(f)

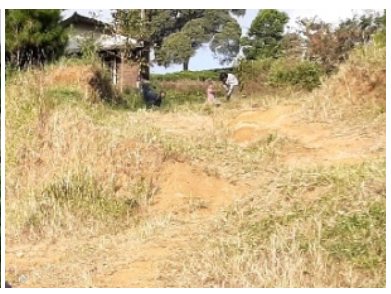

(g)

Figure 1 The research sites: (a) natural forest; (b) complex agroforestry; (c) simple agroforestry; (d) tea plantations; (e) coffee plantations; (f) potato fields; and (g) abandoned land 
4. The largest soil aggregate fragmentation was carried out to $1.5-2 \mathrm{~cm}$. It is intended to see the shape, pores, roots, and easily break up the largest aggregate.

5. Then, visual observation of the soil structure was carried out, which includes the size of the soil sample aggregate, visible porous of the soil and roots, and the fragmented soil aggregate.

6. After that, the scoring was carried out and classified into the soil quality score classification (Table 1). The soil quality formula (Ball et al., 2007) is as shown in Equation [1]

VESS Sq score $=\sum_{i=1}^{n} \frac{\text { SqiTi }}{T T}$

Remarks: $\mathrm{Sq}_{\text {score }}=$ Overall VESS score; $\mathrm{Sq}_{\mathrm{i}}=$ VESS score of each identified soil layer; $T_{i}=$ Thickness of each identified soil layer; TT $=$ The total thickness of soil sample block

7. Soil sampling cannot be taken when it is too dry or too wet. If there is heavy rain during or before the observation process, soil sampling can be taken $24-48$ hours after the rain occurs.

Soil sampling Soil sampling was taken by purposive sampling (undisturbed and disturbed soil). Disturbed soil was taken at a depth of $0-20 \mathrm{~cm}$ at three points of the collection representing each type of land use, then the soil from the three points of the collection was composited, so that one land cover type was obtained one soil sample. Disturbed soil samples were used to calculate soil organic C content, while undisturbed soil samples were used to calculate soil bulk density, porosity, and permeability.

Measurement of crown density and litter weight Measurement of canopy density and litter weight is intended as supporting data which is carried out at each research site. Canopy density and litter weight will help describe the condition of vegetation components for each type of land use. The litter weight will also be related to organic matter. Canopy density measurements were carried out on each plot of land use using a densiometer. Data were collected from the points of light reflected by the densiometer that are covering the four points of each frame. The procedure was repeated for each of the four cardinal points (north, south, east, and west). The results of the canopy density measurement will obtain a density value of $1-100 \%$ (Arief, 2005). Sum up the illuminated points and multiply the mean of points by 1.04 . The coverage canopy is the reverse of that result (1/Openness) (Freitas et al., 2017). Measurement of litter weight was carried out by taking litter from the observation plot location with $1 \mathrm{~m} \times 1 \mathrm{~m}$ subplot, with three repetitions. Then, the litter was put into a plastic bag or envelope. After that, the envelope was weighed to calculate the wet weight (WW), and then to get the dry weight (DW), it was dried in an oven at $60{ }^{\circ} \mathrm{C}$ for 24 hours. Litter weight was obtained from the difference between WW-DW as shown in Equation [2].

Litter weight $\left(\mathrm{g} \mathrm{m}^{-2}\right)=\mathrm{WW}-\mathrm{DW}$

Data analysis Data analysis was carried out to determine the effect of land use on the VESS score. The data were analyzed using analysis of variance (ANOVA). If the result shows a real effect, it will be followed by the Duncan Test to find out the best results based on the ordering. Then, correlation analysis (Pearson's correlation) was performed between the VESS scores and soil property parameters to get the relationship between VESS scores and soil property parameters. Data analysis was performed using Microsoft Excel and SPSS 23 software.

\section{Results and Discussion}

VESS soil sampling was carried out at six types of land uses. The type of soil at those locations is andosol. The VESS soil sample was taken at one point for about 15-20 minutes. Soil conditions at the time of sampling were not too dry and also not too wet. It supports the process of taking VESS soil samples. Ball et al. (2016) states that one of the recommendations for conducting soil sampling with the VESS method is to avoid extreme wet or dry soil conditions. If the soil conditions are too wet (extreme), it will be difficult to identify the differences and aggregate characteristics of the soil samples, whereas if the soil is too dry, it will be difficult to collect soil samples or need a longer time to collect soil samples (Giarola et al., 2013).

The VESS score for each site ranged from 1.3-4.33 (Figure 2). It describes the different soil quality for each type of land use, ranging from very good to poor soil quality. A smaller VESS score indicates better soil quality (Ball et al., 2016). Good soil quality was found in natural forests (Sq 1.3) and complex agroforestry (Sq 1.89). Soil block samples taken in these areas were very easily destroyed at the time of observation, even the aggregates readily crumble with fingers. Based on the VESS method, another factor influencing the soil quality in this area is that the crushed soil samples are dominated by crumbs. In addition, there were a lot of roots in the crushed soil samples and the fragment $(\sim 1.5$ $\mathrm{cm}$ ) (Figure 3). Based on Cherubin et al. (2019), soil slices were easily extracted in the forest and there were many roots in crushed soil. The vigorous root system may benefit soil aggregation by the entanglement of particles, root penetration, changes in soil water status and exudation of organic molecules (Six et al., 2004). That is also thought to be due to the many spaces and pores in the soil that support the roots to penetrate. According to (Bodner et al., 2014; Gao et

Table 1 Soil quality score classification (Ball et al., 2007)

\begin{tabular}{ccl}
\hline Sq score & Soil structural quality & \multicolumn{1}{c}{ Management needs } \\
\hline $1-2$ & Good & No changes need \\
$2-3$ & Fair & Long-term improvements \\
$3-5$ & Poor & Short-term improvements \\
\hline
\end{tabular}




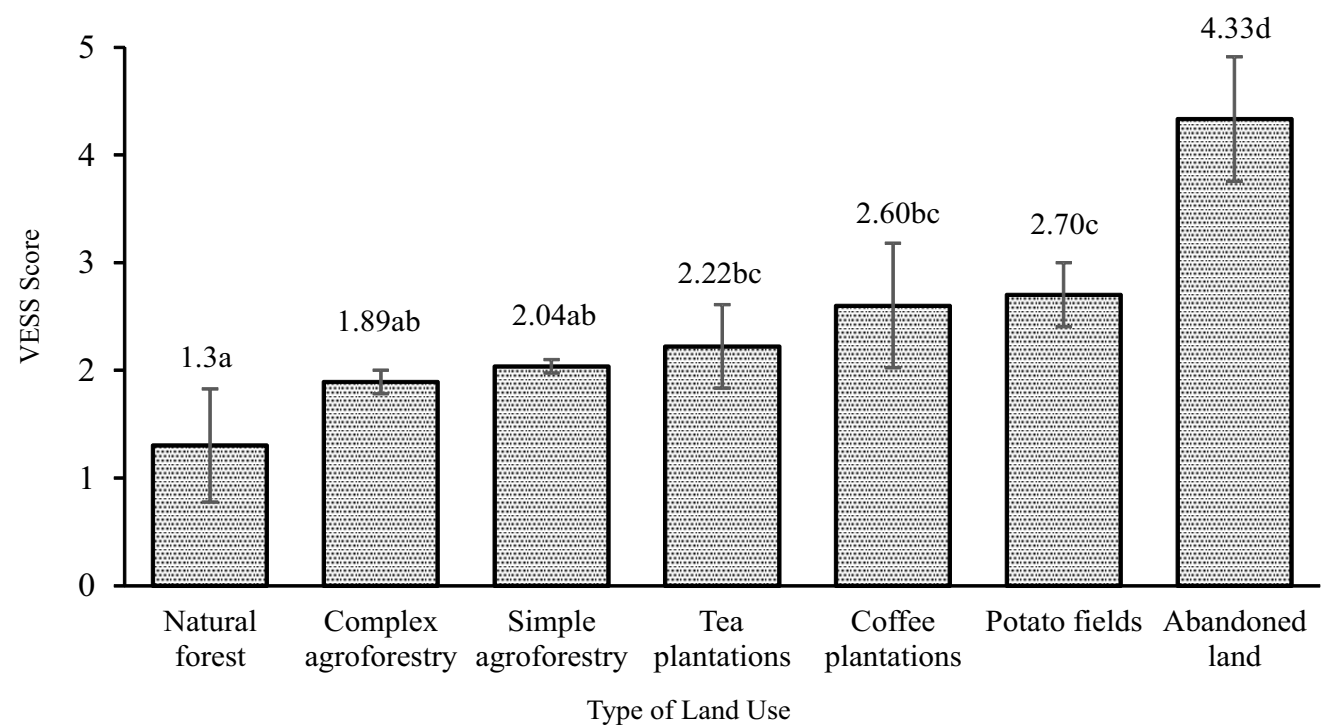

Note: The treatment had a significant effect on the $95 \%$ confidence interval with a significant value ( $p$-value $)<0.05(\alpha)$. The numbers followed by the same letter indicate that the treatments were not significantly different at the $95 \%$ confidence interval.

Figure 2 VESS average score chart for each research site.

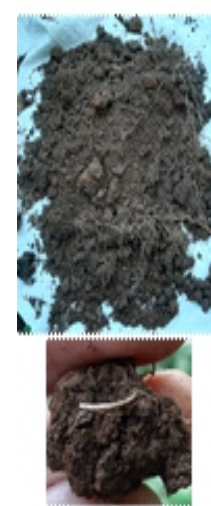

(a)

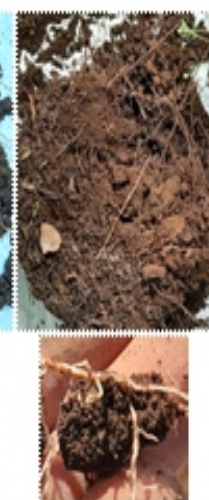

(b)

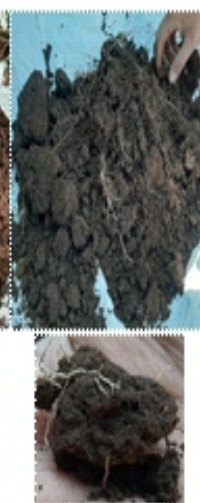

(c)

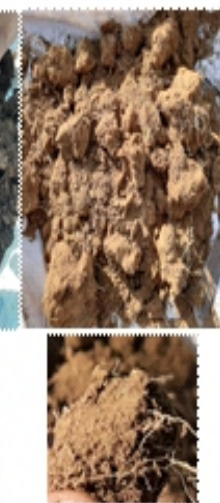

(d)

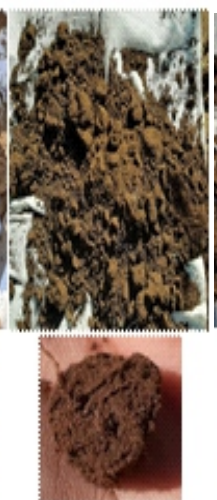

(e)

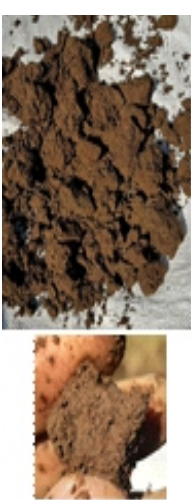

(f)

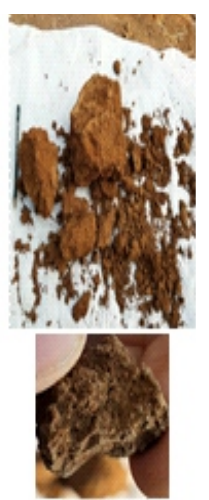

(g)

Figure 3 Cross section and aggregate form $(\sim 1.5 \mathrm{~cm})$ : (a) natural forest; (b) complex agroforestry; (c) simple agroforestry; (d) tea plantations; (e) coffee plantations; (f) potato fields; and (g) abandoned land.

al., 2016), roots can optimally adapt to good soil conditions, so that they can also contribute to the formation of macroaggregates or microaggregates in the soil. Good soil structure is also thought to be influenced by vegetation components in those area. The vegetation component in the natural forest and complex agroforestry are dominated by trees. They produce a lot of litter as organic matter (Table 2). The availability of organic matter can also stimulate soil fauna activity. One of the characters of good soil structure is also influenced by the presence and activity of soil fauna (Tolaka et al., 2013; Bottinelli et al., 2015; Llado et al., 2018; Sun et al., 2020). The organic matter content has an important role in forming more soil pores (Putinella, 2014; Sandrawati et al., 2016), although soil texture is also important in influencing the function of soil structure. Batey (2000), remarked that in subsoils dominated by sand, root penetration may be poor without obvious signs of compaction or hardness.

The fair VESS score (Sq 2.04-2.7) was found on simple agroforestry, tea plantations, coffee plantations and potato fields. It is because medium-large shards of soil aggregates dominate in coffee plantations and potato fields. Medium-large shredded soil aggregates are found in small amounts in simple agroforestry and tea plantations. In addition, aggregates slitting to $1.5-2 \mathrm{~cm}$ is very important to score the soil quality in those areas because it is very helpful in differentiating between two soil quality scores (Cherubin et al., 2019). In some land uses, the fragment $(\sim 1.5 \mathrm{~cm})$ has 
Table 2 Number of vegetation types, litter weight, canopy density, soil bulk density, soil porosity, soil permeability, and soil organic carbon in each research site

\begin{tabular}{|c|c|c|c|c|c|c|c|}
\hline Type of land use & $\begin{array}{c}\text { Vegetation } \\
\text { types } \\
\text { (number) }\end{array}$ & $\begin{array}{c}\text { Litter } \\
\text { weight } \\
\left(\mathrm{g} \mathrm{m}^{-2}\right)\end{array}$ & $\begin{array}{l}\text { Canopy } \\
\text { density } \\
(\%)\end{array}$ & $\begin{array}{c}\mathrm{BD} \\
\left(\mathrm{g} \mathrm{cc}^{-1}\right)\end{array}$ & $\begin{array}{l}\text { Po } \\
(\%)\end{array}$ & $\begin{array}{c}\mathrm{Pe} \\
\left(\mathrm{cm} \mathrm{hour}^{-1}\right)\end{array}$ & $\begin{array}{l}\text { SOC } \\
(\%)\end{array}$ \\
\hline $\begin{array}{l}\text { Natural forest } \\
(20 \times 20) \mathrm{m}\end{array}$ & $\begin{array}{l}\text { Castanopsis } \\
\text { sp. (4), } \\
\text { Rubiaceae (6), } \\
\text { palms (6) }\end{array}$ & 157.23 & 81 & 1.05 & 60.36 & 1.13 & 20.61 \\
\hline $\begin{array}{l}\text { Complex } \\
\text { agroforestry }(20 \times 20) \\
\text { m }\end{array}$ & $\begin{array}{l}\text { Eucalyptus } \\
\text { (7), jackfruit } \\
\text { (3), Biwa (2), } \\
\text { Suren (3), } \\
\text { coffee (71) }\end{array}$ & 244.07 & 71 & 1.08 & 59.17 & 1.16 & 14.07 \\
\hline $\begin{array}{l}\text { Simple agroforestry } \\
(20 \times 20) \mathrm{m}\end{array}$ & $\begin{array}{l}\text { Eucalyptus } \\
\text { (9), coffee } \\
(65)\end{array}$ & 212.87 & 65 & 1.10 & 58.31 & 1.10 & 14.14 \\
\hline $\begin{array}{l}\text { Tea plantations } \\
(20 \times 20) \mathrm{m}\end{array}$ & Tea (40) & 29.37 & 0 & 1.23 & 53.72 & 1.07 & 6.94 \\
\hline $\begin{array}{l}\text { Coffee plantations } \\
(5 \times 15) \mathrm{m}\end{array}$ & Coffee (51) & 44.23 & 0 & 1.19 & 55.21 & 1.05 & 14.76 \\
\hline $\begin{array}{l}\text { Potato fields } \\
(0.3 \mathrm{ha})\end{array}$ & $\begin{array}{l}\text { Potato } \\
(+/-2000)\end{array}$ & - & 0 & 1.36 & 48.84 & 1.06 & 6.16 \\
\hline Abandoned land & - & - & 0 & 1.60 & 39.66 & 1.01 & 0.81 \\
\hline
\end{tabular}

fewer pores and roots, as in coffee plantations and potato fields. Simple agroforestry and tea plantations are slightly better because the fragments $(\sim 1.5 \mathrm{~cm})$ have many roots. This is thought to be influenced by the vegetation component and land management. Agricultural land under intensive management has positive effects in the short term, however, it will have a negative impact in the long term, such as degradation of soil structure (Cherubin et al., 2016b). According to Ball et al. (2007), fair soil quality only requires long-term soil improvement.

Abandoned land has poor soil structure quality with the VESS score $\mathrm{Sq}$ 4.33. The process of observing the soil structure in this area was very difficult because the characteristics of the soil are too dense, so the sampling of soil on this area took a longer time. The process of crushing soil samples was also very difficult. The form of aggregate $(\sim$ $1.5 \mathrm{~cm}$ ) in the abandoned land sample was characterized by cracks and sharp angles at several corners of the soil aggregate (Figure 2). According to Moncada et al. (2014), soil aggregates that have angular angles at the ends are soil with poor structural quality. Abandoned land has no vegetation component on it so that it allows soil compaction. Soil degradation can be caused by soil compaction and loss of biological - chemical processes (Guimaraes et al., 2016; Guimaraes et al., 2017). Compaction alters many soil properties and adverse effects are mostly linked to a reduction in permeability to air, water, and roots (Batey, 2009).

The role of agroforestry on soil properties One of the positive effects of agroforestry systems in this study is their effect on soil quality. The agroforestry system has a relatively good VESS score, complex agroforestry with Sq 1.89 and simple agroforestry with $\mathrm{Sq} 2.04$. The score is lower when compared to other types of land use such as tea plantations, coffee plantations, potato fields, and abandoned land, although the scores on agroforestry areas are still higher than the VESS score of natural forests. It is sufficient to illustrate that the soil structure quality of agroforestry is quite good compared to other types of land use, although it is not as good as the soil structure in natural forests.

Agroforestry (complex and simple) has better soil properties compared to other types of land use. Soil properties include soil bulk density, soil porosity, soil permeability, and soil organic carbon (Table 2). Agroforestry areas have soil bulk density of $1.08 \mathrm{~g} \mathrm{~cm}^{-3}$ and $1.1 \mathrm{~g} \mathrm{~cm}^{-3}$, soil porosity of $59.17 \%$ and $58.31 \%$, soil permeability of $1.16 \mathrm{~cm}$ hour $^{-1}$ and $1.1 \mathrm{~cm}$ hour $^{-1}$, and soil organic carbon of $14.07 \%$ and $14.14 \%$. This shows that the practice of agroforestry systems can have a positive effect on soil quality. Based on the research conducted by Stocker et al. (2019), agroforestry practices can improve several aspects of soil physical properties such as bulk density, total porosity, and C-organic total in a short period of time. It is in line with (Istomo et al., 2011), that agroforestry practices that have a relatively bulk density will allow a lot of water to be absorbed into the soil. Agroforestry practices can also increase soil fertility through enrichment of organic matter, tree vegetation, and soil microbial activity (Dollinger \& Jose, 2018). In this study, factors affecting soil quality in agroforestry areas include the amount of vegetation, canopy density, and availability of litter which can trigger microorganism activity.

Vegetation components in agroforestry areas consisting of trees and coffee affect the nutrient cycle, which is almost like the nutrient cycle in natural forests. Based on Raj et al. (2017), the combination of trees and field crops in agroforestry can increase the nutrient uptake and their management practices that lead to improved organic matter 
status of the soil will lead inevitably to improved nutrient cycling and better soil productivity. Agroforestry is sustainable land-use systems that help in improving soil fertility as a long-term benefit. It helps in increasing productivity, improving nutrient cycling and also improving socio-economic status of farmers (Misra, 2011). The amount of vegetation in the agroforestry area is directly proportional to the amount of litter produced (Table 2). Planting tree species in an agroforestry system has an effect on good physical soil conditions through the distribution of various root patterns. Cherubin et al. (2019) argued that agroforestry practices can improve the physical quality of the soil as the land ages and the diversity of vegetation on the land increases. The trees have deep roots and spread intensively in the soil layer thereby reducing nutrient leaching (Suryani \& Dariah, 2012). Canopy density on complex agroforestry area was $71 \%$ and on simple agroforestry areawas $65 \%$. According to Suarsana et al. (2016), a high canopy density can repel raindrops that fall to the ground so as to reduce the rate of erosion.

Both agroforestry areas have litter weights of $244.07 \mathrm{~g} \mathrm{~m}^{-2}$ in complex agroforestry and $212.87 \mathrm{~g} \mathrm{~m}^{-2}$ in simple agroforestry (Table 2). Litter contribution certainly affects soil properties. Litter availability will have a positive correlation with the number of soil microfauna types (Susanti \& Halwany, 2017; Llado et al., 2018; Sun et al., 2020). Soil with sufficient organic matter content will usually have crumbly and stable aggregates, then soil organic matter can also create a balanced pore space between micro and macro pores for water transmission and retention (Yulnafatmawita et al., 2008). Organic matters can spur the formation of soil aggregates, because they form mycela,
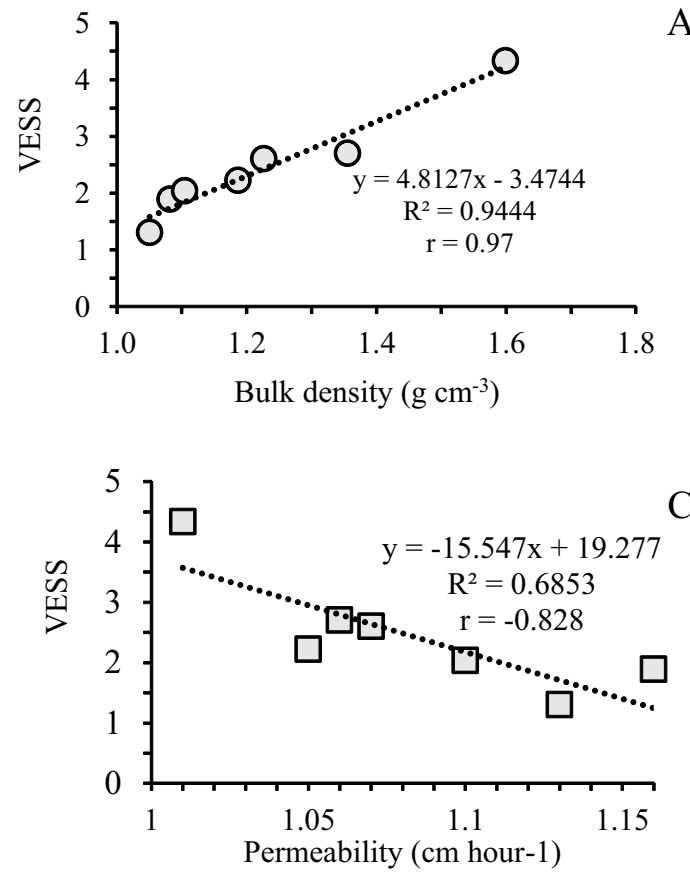

mucus, and sludges compounds due to the activity of microorganisms (Gregorich et al., 2006). The sludge functions as an adhesive for soil grains into soil aggregates, then into pores that can store water and drain air. Organic matter can also increase soil plasticity (Abdi et al., 2018). The availability of litter can also increase the availability of nutrients in the soil (Aprianis, 2011).

Relationship between VESS score and soil properties This study showed that the VESS score and the results of soil physical properties have a good correlation (Figure 4). It means that the VESS score is quite efficient to use to evaluate the physical quality of the soil. The best correlation is found in the relationship between VESS scores and soil bulk density, with a value of $r=0.97$, while the VESS score with soil porosity has a negative correlation, with a value of $r=$ 0.97. The good correlation between VESS score and soil bulk density is in line with the previous studies (Guimaraes et al., 2013; Tuchtenhagen et al., 2017; Cherubin et al., 2019). According to Johannes et al. (2016), the correlation between soil porosity and VESS score will affect the nature of the porosity structure of the soil. Another relationship shows that the VESS score also correlates well with the $\mathrm{C}$-organic value and soil permeability. The VESS and C-organic correlation has $r=-0.94$. This correlation value is the same as studies conducted by Moncada et al. (2014), Tuchtenhagen et al. (2017), Cherubin et al. (2019). The correlation between VESS and soil permeability has a value of -0.828 . It is the lowest correlation value when compared to other soil properties, but it is still classified into a fairly good correlation.
A
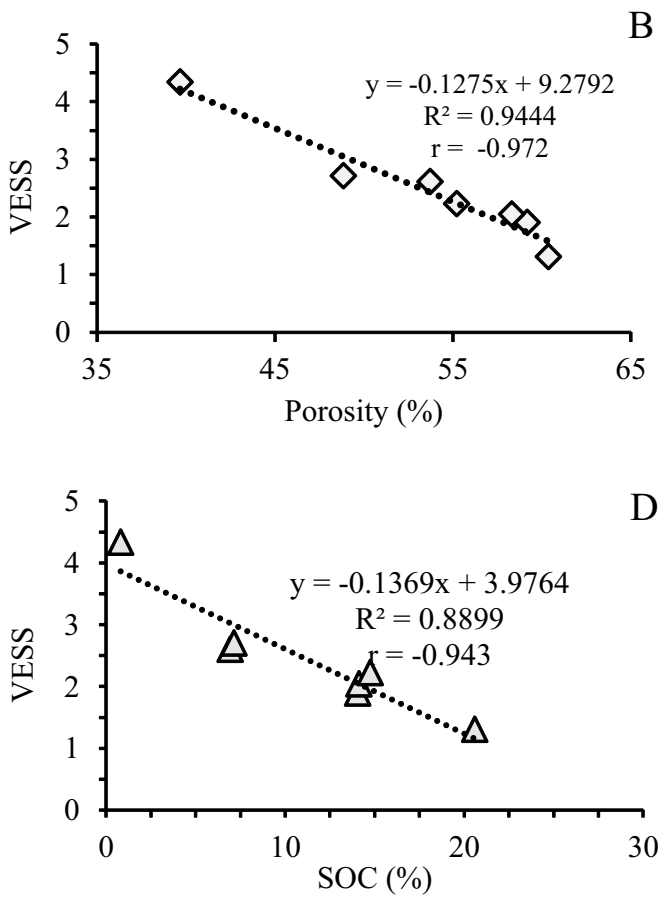

Figure 4 Correlation between VESS scores and soil properties: (a) soil bulk density, (b) soil porosity, (c) soil permeability, and (d) soil organic carbon. 
The VESS score which has a good correlation with soil indicators is a key in determining soil quality (Ball et al., 2018). If the soil has good physical quality, it will lead to improvements in soil biological and chemical properties, although more detail research is needed on the relationship between soil physical quality and soil fertility (Ball et al., 2016). VESS method is also easy to apply in this research. Cherubin et al. (2019) stated that the VESS method has the advantage of easy understanding, little equipment, and can be applied in places that are difficult for humans to reach.

The VESS method can be used in evaluating the physical degradation of soil due to land use, even it can be used for monitoring the physical quality of soil during mine reclamation. According to Franco et al. (2019), the VESS method has begun to be widely used in the world, not only in temperate countries, but also in sub-tropical and tropical countries. Paiva et al. (2020) state that the VESS method is the most widely known method and used to evaluate soil quality among communities and even universities. Based on the results of this study and several studies on other VESS methods, it is expected that this method can be used by various groups such as researchers, students, farmers, and land managers to determine or evaluate soil quality.

\section{Conclusion}

The VESS scores of natural forest and complex agroforestry is classified as good soil quality. Simple agroforestry, tea plantations, coffee plantations, and potato fields had fair VESS scores. Abandoned land has a relatively poor VESS score, Thus it is recommended for short-term soil improvement. The difference in VESS scores is thought to be influenced by vegetation components, canopy density, litter availability, and soil management in certain areas, such as fertilization. This also affects soil bulk density, soil porosity, soil permeability, and soil organic carbon. The physical quality of agroforestry areas (complex and simple) is not much different from natural forest. VESS method is easy to apply and requires little equipment. The VESS score has a good correlation with soil property parameters. It shows that VESS method is efficient to evaluate the physical quality of the soil in this study.

\section{Recommendation}

Research for VESS method must be reproduced in order to support reference and improvement of the method itself, especially in relation to the application of the VESS method to different soil types. Then, more research needs to be done in terms of the VESS method with the proportion of soil texture fraction. Another thing that needs to be done is to trace the link between the results of the VESS method with soil chemical and biological properties, such as the relationship between the VESS value and the presence and activity of soil fauna.

\section{References}

Abdi, E., Babapour, S., Majnounian, B., Amiri, G. Z., \& Deljouei, A. (2018). How does organic matter affect the physical and mechanical properties of forest soil. Journal of Forestry Research, 29(3), 657-662. https://doi.org/

\section{$10.1007 / \mathrm{s} 11676-017-0494-4$}

Aprianis, Y. (2011). Produksi dan laju dekomposisi Acacia crassicarpa A. Cunn. di PT. ARARA ABADI. Tekno Hutan Tanaman, 4(1), 41-47.

Arief, A. (2005). Hutan dan kehutanan. Jakarta: Kanisius.

Ball, B. C., Batey, T., \& Munkholm, L. J. (2007). Field assessment of soil structural quality-a development of the Peerlkamp test. Soil Use and Management, 23, 329-337. https//doi.org/10.1111/j.1473-2743.2007.00102.x

Ball, B. C., Guimaraes, R. M. L., Cloy, J. M., Hargreaves, P. R., Shepherd, G., \& McKenzie, B. M. (2016). Visual soil evaluation: A summary of some applications and potential developments for agriculture. Soil and Tillage Research, 210. https://doi.org/10.1016/j.still.2016. 07.006

Ball, B. C., Hargreaves, P. R., \& Watson, C. A. (2018). A framework of connections between and people can help improve sustainability of the food system and soil functions. Ambio, 47, 269-283. https://doi.org/10.1007/ s13280-017-0965-Z

Batey, T. (2000). Soil profile description and evaluation. In K. A. Smith, \& C. E. Mullins (Eds.), Soil, and environmental analysis physical methods (pp. 595-628). New York: Marcell Dekker.

Batey, T. (2009). Soil compaction and soil management. Soil Use and Management, 25, 335-345. https://doi.org/ 10.1111/j.1475-2743.2009.00236.x

Bodner, G., Leitner, D., \& Kaul, H. P. (2014). Coarse and fine root plants affect pore size distributions differently. Plant Soil, 380, 133-151. https://doi.org/10.1007/s11104014-2079-8

Bottinelli, N., Jouquet, P., Capowiez, Y., Podwojewski, P., \& Grimaldi, M. (2015). Why is the influence of soil macrofauna on soil structure only considered by soil ecologist? Soil and Tillage Research, 146, 118-124. https://doi.org/10.1016/j.still.2014.01.007

Cherubin, M. R., Karlen, D. L., Cerii, E. P., Franco, L. C., Tormena, C. A., Davies, A. C., \& Cerri, C. C. (2016a). Soil quality indexing strategies for evaluating sugarcane expansion in Brazil. Plos One, 11(3), 126. https://doi.org/10.1371/journal.pone.0150860

Cherubin, M. R., Karlen, D. L., Cerri, E. P., Franco, L. C., Tormena, C. A., Davies, A. C., \& Cerri, C. C. (2016b). Soil physical quality response to surgacane expansion in Brazil. Geoderma, 267, 156-168. https://doi.org/ 10.1016/j.geoderma.2016.01.004

Cherubin, M. R., Franco, L. C., Guimaraes, M. L., Tormena, C. A., Cerri, E. P., Karlen, D., \& Cerri, C. C. (2017). Assessing soil structural quality under Brazilian sugarcane expansion areas using visual evaluation of soil 
structure (VESS). Soil and Tillage Research, 173, 64-74. https://doi.org/10.1016/j.still.2016.05.004

Cherubin, M. R., Bermeo-Chavaro, J. P., \& Olaya-Silva, A. M. (2019). Agroforestry systems improve soil physical quality in Northwestern Colombian Amazon. Agroforestry System Journals, 93, 1741-1753. https://doi.org/10.1007/s10457-018-0282-y

Cui, J., Askari, M. S., \& Holden, N. M. (2014). Visual evaluation of soil structure under grassland management. Soil Use and Management, 30, 129-138. https://doi.org/ 10.1111/sum. 12100

Dollinger, J., \& Jose, S. (2018). Agroforestry for soil health. Agroforestry System Journals, 92, 213-219. https://doi.org/10.1007/s10457-018-0223-9

Franco, H. H. S., Guimaraes, R. M. L., Tormena, C. A., Charubin, M. R., \& Favilla, H. S. (2019). Global applications of the visual evaluation of soil structure method: A systematic review and meta-analysis. Soil and Tillage Research, 190, 61-69. https://doi.org/10.1016/ j.still.2019.01.002

Freitas, M. A., Masseli, G. S., Marques, S., \& Costa, F. (2017). Protocol for using the forest densiometer in RAPELD plots. Brazil: PPBio.

Gao, W., Hodgkinson, L., Jin, K., Watts, C. W., Ashton, R. W., Shen, J., ..., \& Whalley, W. R. (2016). Deep roots and soil structure. Plant, Cell, and Environment, 39, 1662-1668. https://doi.org/10.1111/pce.12684

Ghezzehei, T. A. (2012). Soil structure. Merced: University of California.

Giarola, N. F. B., Da Silva, A. P., Tormena, C. A., Guimaraes, R. M. L., \& Ball, B. C. (2013). On the visual of soil structure: The Brazilian experience in oxisols under notillage. Soil and Tillage Research, 127, 60-64. https://doi.org/10.1016/j.still.2012.03.004

Gregorich, E. G., Beare, M. H., McKim, U. F., \& Skjemstad, J. O. (2006). Chemical and biological characteristics of physically uncomplexed organic matter. Soil Science Society of America Journal, 70, 975-985. https://doi.org/ 10.2136/sssaj2005.0116

Guimaraes, R. M. L., Ball, B. C., \& Tormena, C. A. (2011). Improvements in the visual of soil structure. Soil Use and Management, 27, 395-403. https://doi.org/10.1111/ j.1475-2743.2011.00354.x

Guimaraes, R. M. L., Ball, B. C., Tormena, C. A., Giarola, N. F., \& Da Silva P. A. (2013). Relating visual evaluation of soil structure to other physical properties in soils of contrasting texture and management. Soil and Tillage Research, 127, 92-99. https://doi.org/10.1016/ j.still.2012.01.020

Guimaraes, R. M. L., Junior, A. F. N., Silva, W. G., Rogers, C.
D., Ball, B. C., Montes, C. R., \& Pereira, B. F. F. (2016). The merits of the visual evaluation of soil structure method (VESS) for assessing soil physical quality in the remote, undeveloped regions of the Amazon basin. Soil and Tillage Research, 173, 75-82. https://doi.org/ 10.1016/j.still.2016.10.014

Guimaraes, R. M. L., Lamande, M., Munkholm, L. J., Ball, B. C., \& Keller, T. (2017). Opportunities and future directions for visual soil evaluation methods in soil structure research. Soil and Tillage Research, 173, 104-113. https://doi.org/10.1016/j.still.2017.01.016

Istomo, Wasis, B., \& Prihatiningtyas E. (2011). Pengaruh agroforestri jarak pagar (Jatropha curcas Linn.) terhadap produktivitas lahan dan kualitas lingkungan di areal Perum Perhutani KPH Bogor. Jurnal Silvikultur Tropika, 3(1), 113-118.

Johannes, A., Weisskopf, P., Schulin, R., \& Boivin, P. (2016). To what extent do physical measurements match with visual evaluation of soil structure? Soil and Tillage Research, 173, 24-32. https://doi.org/10.1016/ j.still.2016.06.001

Llado, S., Mondejar, R. L., \& Baldrain, P. (2018). Drivers of microbial community structure in forest soils. Applied Microbiology and Biotechnology, 102, 43-31. https://doi.org/10.1007/s00253-018-8950-4

Misra, P. K. (2011). Soil fertility management in agroforestry system. International Journal of Biotechnology and Biochemistry, 7(5), 637-644.

Moncada, M. P., Gabriels, D., Lobo D., Rey, J. C., \& Cornelis, W. M. (2014). Visual assessment of soil structural quality in tropical soils. Soil and Tillage research, 139, 8-18. https://doi.org/10.1016/j.still. 2014.01.002

Paiva, I. A. D., Rita, Y. L., \& Polizeli, K. M. C. (2020). Knowledge and use of visual soil structure assessment methods in Brazil - A survey. Soil and Tillage Research, 204, 104704. https://doi.org/10.1016/j.still.2020.104704

Prasetya, B., Prijono, S., \& Widjiawanti, Y. (2012). Vegetasi pohon hutan memperbaiki kualitas tanah andisolNgabab. Indonesian Green Technology Journal, 1(1), 16.

Putinella, J. A. (2014). Perubahan distribusi pori tanah regosol akibat pemberian kompos ela sagu dan pupuk organik cair. Buana Sains, 14(2), 123-129.

Rabot, E., Wiesmeier, M., Schluter, S., \& Vogel, H. J. (2018). Soil strucuture as an indicator of soil functions: A review. Geoderma, 314, 122-137. https://doi.org/10.1016/ j.geoderma.2017.11.009

Raj, A., Jhariya, M. K., Toppo, P., \& Oraon, P. R. (2017). Role of agroforestry in nutrient cycling. KISAN WORLD, 44(7), 38-40. 
Rahmayuni, \& Rosneti. (2017). Kajian beberapa sifat fisika tanah pada tiga penggunaan lahan di Bukit Batabuh. Jurnal Agrosains dan Teknologi, 2(1), 1-11.

Sandrawati, A., Setiawan, A., \& Kesumah, G. (2016). Pengaruh kelas kemiringan lereng dan penggunaan lahan terhadap sifat fisik tanah di Kawasan Penyangga Waduk Cirata Kecamatan Cipeundeuy Kabupaten Bandung Barat. Soilrens, 14(10), 114-128.

Schumacher, T. E. \& Riedell, W. E. (2008). Soil structure examined. Washington: Science.

Setyowati, G. L. (2007). Sifat fisik tanah dan kemampuan tanah meresapkan air pada lahan hutan, sawah, dan pemukiman. Jurnal Geografi, 4(2), 114-128.

Silva, G. L., Lima, H. V., Campanha, M. M., Gilkes, R. J., \& Oliveira, T. S. (2011). Soil physical quality of luvisols under agroforestry, natural vegetation, and conventional crop management systems in the Brazilian semi-arid region. Geoderma, 167, 61-70. https://doi.org/10.1016/ j.geoderma.2011.09.009

Six, J., Bossuyt, H., Degryze, S., \& Denef, K. (2004). A history of research on the link between (micro)aggregates, soil biota, and soil organic matter dynamics. Soil \& Tillage, 79, 731. https://doi.org/ 10.1016/j.still.2004.03.008

Stocker, C. M., Bamberg, A. L., Stumpf, L., Monteiro, A. B., Cardoso, J. H., \& Lima, A. C. R. (2019). Short-term soil physical quality improvements promoted by an agroforestry system. Agroforestry Systems Journals, 94, 2053-2064. https://doi.org/10.1007/s10457-020-005243

Suarsana, I. W., Merit, I. N., \& Adnyana, I. W. S. (2016). Prediksi erosi, klasifikasi kemampuan lahan dan arahan penggunaan lahan di Kecamatan Baturiti, Kabupaten Tabanan, Provinsi Bali. ECOTROPHIC, 10(2), 148-158.
Sun, Y., Luo, C., Jiang, L., Song, M., Zhang, D., Li, J., Li, Y., Ostle, N. J., \& Zhang, G. (2020). Land-use changes alter soil bacterial composition and diversity in tropical forest soil in China. Science of the Total Environment, 712, 210. https://doi.org/10.1016/j.scitotenv.2020.136526

Suryani, E. \& Dariah, A. (2012). Peningkatan produktivitas tanah melalui sistem agroforestri. Jurnal Sumberdaya Lahan, 6(2), 101-109.

Susanti, P. D. \& Halwany, W. (2017). Dekomposisi serasah dan keanekaragaman makrofauna tanah pada hutan tanaman industri nyawai (Ficus variegate. Blume). Jurnal Ilmu Kehutanan, 2, 212-223.

Tolaka, W., Wardah, \& Rahmawati. (2013). Sifat fisik tanah pada hutan primer, agroforestri, dan kebun kakao di Subdas Wera Saluopa Desa Leboni Kecamatan Pamona Puselemba Kabupaten Poso. Warta Rimba, 1(1), 1-8.

Tormena, C. A., Karlen, D., Logsdon, S. D., \& Cherubin, M. R. (2016). Visual soil structure effects of tillage and corn stover harvest in Lowa. 2016. Soil Science Society of America Journal, 80, 720-726. https://doi.org/10.2136/ sssaj2015.12.0425

Tuchtenhagen, I. K., De Lima, C. L. R., Bamberg, A. L., Guimaraes, R. M. L., \& Moncada, M. P. (2017). Visual evaluation of the soil structure under different management systems in lowlands in Southern Brazil. Revista Brasileira de Ciencia do Solo, 42. https://doi.org/ 10.1590/18069657rbcs20170270

Undang, K., \& Nurida, N. L. 2009. Perubahan agregat tanah pada ultisols Jasinga terdegradasi akibat pengolahan tanah dan pemberian bahan organik. Jurnal Tanah dan Iklim, 30, 37-46.

Yulnafatmawita, Naldo, R. A., \& Rasyidin, A. (2008). Analisis sifat fisika ultisol tiga tahun setelah pemberian bahan organik segar di daerah Tropis Basah Sumbar. Jurnal Solum, 9(2), 91-97. 